\title{
In search of peace: Ahmadi women's experiences in conflict transformation
}

\author{
Nina Mariani Noor \\ Siti Syamsiyatun, JB. Banawiratma \\ Inter Religious Studies, ICRS Universitas Gadjah Mada \\ E-mail:nina.mariani@yaboo.co.id
}

In the last few years, religious conflicts involving a minority Muslim group, Ahmadiyya, have risen dramatically in Indonesia; the most recent being the attack on the Ahmadiyya community in Cikeusik Banten, West Java, where three Ahmadis were killed and the sealing of Al Mishbah Mosque by local government of Bekasi West Java. Understanding the context of violent conflict and the ways individual Ahmadi women take agency to challenge such oppression is an important first step in creating a more equitable and peaceful Indonesia. To examine the experience of Ahmadi women exercising their agency in conflict transformation, this qualitative research was conducted in four areas of Indonesia: Bogor, Kuningan, Yogyakarta and Lombok, by gathering data from the narratives of Ahmadi women who actively participate in Lajnah Imaillah, an Ahmadiyya's women's organization. This research highlights three stages of conflict transformation that the women employed: 1) asking for government help; 2) taking physical action to defend their rights; and 3) defining themselves as Indonesian citizens who have the same rights as others. Through these actions, they show their ability to help others, transforming the conflict by forming better relationships and understanding with other Indonesian citizens.

Dalam beberapa tahun terakhir, konflik keagamaan yang melibatkan sebuah kelompok minoritas muslim, Ahmadiyah, meningkat drastis di Indonesia; yang terbaru adalah penyerangan komunitas Ahmadiyah di Cikeusik Banten, Jawa Barat di mana tiga Ahmadi terbunuh dan penyegelan masjid Al Mishbah oleh pemda Bekasi. Memahami konteks konflik dengan kekerasan dan cara-cara perempuan Ahmadi menggunakan agensi mereka adalah sebuah langkah penting dalam mewujudkan Indonesia yang setara dan damai. Untuk membahas pengalaman perempuan Ahmadi dalam mempraktekkan agensi mereka dalam transformasi konflik, penelitian kualitatif ini dilaksanakan di empat area di Indonesia: Bogor, Kuningan, Yogyakarta dan Lombok, dengan pengumpulan data dari narasi perempuan Ahmadi yang aktif di Lajnah Imaillah, organisasi untuk perempuan Ahmadi. Penelitian ini menggarisbawahi tiga tahap transformasi konflik yang dilakukan perempuan Ahmadi; 1) meminta bantuan dari pemerintah 2) menggunakan kekuatan fisik untuk mempertahankan hak, dan 3) menempatkan diri sebagai warga Negara yang mempunyai hak sama dengan lainnya. Melalui aksi-aksi yang mereka lakukan, mereka 
ljtihad, Jurnal Wacana Hukum Islam dan Kemanusiaan, Volume 15, No. 1, Juni 2015: 61-82

menunjukkan bahwa mereka bisa membantu lainnya dan mentransformasi konflik dengan menjalin hubungan dan pengertian yang lebih baik dengan warga negara Indonesia lainnya.

Keywords: Conflict transformation; Abmadiyya; Abmadi women; Peace; Conflict

\section{Introduction}

Conflicts with religious background involving Ahmadiyya community Indonesia have rose dramatically in the last few years. The most recent, in February 2011, was the attack on the Ahmadiyya community in Cikeusik Banten, West Java, where three Ahmadis (people who join in Ahmadiyah) were killed. Ahmadiyya Indonesia is part of Ahmadiyya international and it is a minority Muslim group among mainstream Muslims in Indonesia. Its different interpretation on 'khataman nabiyyin' (the last prophet) makes it viewed as a heretical sect in Islam.

Conflict with violence faced by Ahmadiyya community gives impact not only to Ahmadi men but also Ahmadi women. When there is a violence happening, their whole communities have to cope with it. They partake their part in response to the conflict. I chose Ahmadi women as the subject of my research, because women, in terms of conflict resolution, according to Golan Galia, a sociologist and peacemaker activist in Palestine -Israel conflict, may have a different perspective from that of men, one connected with individual wellbeing. Women may see "security" in terms of shelter, food and health, while men tend to perceive security in terms of weapons systems and arms. Galia further states that it is likely that "women would tend to approach peace from a human rights perspective, which would emphasize fairness, tolerance, respect for difference, for minorities, for "the other," because women live as "the other," as a minority - not in numbers but in the attitude toward them in society". Thus, the protection of personal rights, fairness and respect for difference may get a greater attention from women. Fortunately, those elements are the key elements to peacemaking and conflict resolution (Galia, 2004: 92-96).

Furthermore, based on some research done on conflicts, it has been found that women are often prepared to see conflict as opportunity to build a relationship while a man sees conflict as an element of and a prospect for competition. Moreover, feminists from the nineteenth century have asserted that when women accomplish full and equal participation in society they will be a distinctive and vital contribution to conflict resolution and peace 
social order (Berg, 1994: 325-348).

This paper investigates and elaborates conflict transformation process and efforts done by Ahmadi women through its organization Lajnah Imaillah (Wings organization of Ahmadiyya Community for Ahmadi women) in dealing with conflict with violence that they experience related to their faith from after Reformasi era till 2014.

This paper consists of several parts. The first part is introduction, the second is literature review followed by theoretical framework for the paper. The next parts are discussion on the exercising agencies done by Ahmadi women in the process of conflict transformation in the context of discrimination and violence they face. Concluding remarks highlights some important points discussed in the paper and possible future research.

\section{Researching and portraying Ahmadiyya in Indonesia}

Several studies have been done related to Ahmadiyya in Indonesia. There are some studies that concern about the persecution and conflict that have been faced by this community. For example, Ali Amin's thesis in Center for Religious and Cross-cultural Studies, Universitas Gadjah Mada, titled "Intra-religious Persecution in West Java. As Case Study of Ahmadiyah Community in Manislor Kuningan" (2005) and Erni Budiwanti’s "Pluralism Collapses: A Study of Jama'ah Ahmadiyah Indonesia and its Persecution" (2009). Doing research in Ahmadiyya community in Manislor Kuningan West Java, Ali Amin (2005) finds out that relating to persecution experienced by them that there is an important phenomenon of state hegemony over the society using the instruments of religion. Religion has become another tool of government to strengthen its position over the society through regulation, education and media. While Erni Budiwanti (2009: 3) highlights the government's interference on Ahmadiyya's case which only worsened the conflicts. A bit different from the two former works, Syaiful Anam's thesis in Magister of Conflict Resolution Universitas Gadjah Mada, "Reproduksi Kekerasan Kolektif: studi kasus konflik Ahmadiyah di Lombok NTB tahun 1998 - 2006 (2011) investigated the causes of the collective violence experienced by Jemaat Ahmadiyya in Lombok from 1998 to 2006.

As for studies on Ahmadiyya related to conflict resolution, there are two theses from Conflict Resolution Magister in Graduate School Universitas Gadjah Mada which look at 
ljtihad, Jurnal Wacana Hukum Islam dan Kemanusiaan, Volume 15, No. 1, Juni 2015: 61-82

the role of state apparatus. Agus Pujianto (2007) did research on the role of Sat Brimob (Mobile Brigade, Indonesian National Police special operations force units) district police West Timor (NTB) in executing intervention on the conflicts, whereas R Barata Indrajaya did research on conflict management applied by Polres Mataram in relation to the conflict between Ahmadiyya and non Ahmadiyya in Mataram. Both studies only see conflict resolution from the efforts of apparatus not from Ahmadis. My research fills the gap on it.

Studying Ahmadiyya as an entity, Enny Ingkretia in her research found that Ahmadiyya has, as its internal strength, the cohesiveness which allows the organization to continue to exist up until today although they face many opposition and persecution form other "mainstream Muslims" (Ingkretia, 2011).

In contrast to my own study, the studies above also tend to focus on the Indonesian Ahmadi community in general; research focused specifically on Ahmadi women is still rare, particularly in the Indonesian context. Although globally researchers such as Gosh (2006: 50), has studied Pakistani Ahmadi women in California, USA, and Gualtieri (2004) has studied the social lives of Ahmadi women within Pakistan, there are only two studies published when it comes to Indonesian Ahmadiyya women. Most studies done nowadays in Indonesia have overlooked the existence of Ahmadi women and this circumstance makes Ahmadi women invisible and unheard.

The first study of Indonesian Ahmadi women was done by Dyana Savina Hutadjulu (2009) in which explores the intersectional experiences of different Ahmadiyya women residing in Bogor, Manislor and Padang (Indonesia). She concludes that Ahmadi women from those different areas face different situation in terms of discrimination and protection-a central reason for why I chose to study several different Ahmadi communities myself. The second is by Winy Trianita (2009) who explored Ahmadi women's agency. She found that Ahmadi women independently choose their own religious beliefs and resist discrimination by others which would potentially threaten their faith as religious minorities in Indonesia. In keeping with my own research lens, she found that Indonesian Ahmadi women, as part of a minority group, have actually become agents who clarify common misconceptions toward the Ahmadiyya community that they are "exclusive" by being active in their social activities outside of their community both organizationally and individually. Such research shows that 
there is an active participation of Ahmadi women in dealing with resistance that the Ahmadiyya community faces, and thus serves as a valuable starting point for my own study (Noor, 2010; Noor, 20011). Indeed, my research contributes further research on how Ahmadi women deal with religious conflicts, particularly in relation to conflict transformation but, unlike the studies highlighted above, it is based on their own narratives.

Furthermore, given the circumstances that are now faced by the Ahmadiyya community in Indonesia, this research is making a significant contribution to the knowledge on Ahmadiyya and occupy a special point among all research on Ahmadiyya in Indonesia.

\section{Theoretical framework}

In this paper I use theory of conflict transformation developed by John Paul Lederach. Lederach chooses to use "conflict transformation" rather than "conflict resolution" because according to him, conflict transformation is more accurate. He based it on two realities, "conflict is normal in human relationships, and conflict is a motor of change" (Lederach, 2003).

According to Lederach (2003), conflict transformation is more than a set of specific techniques. "It is about a way of looking and seeing, and it provides a set of lenses through which we make sense of social conflict'. He defines:

"Conflict transformation is to envision and respond to the ebb and flow of social conflict as life-giving opportunities for creating constructive change processes that reduce violence, increase justice in direct interaction and social structures, and respond to real-life problems in human relationships." (Lederach, 2003: 3).

Lederach stresses that a transformational approach begins with two pro-active foundations: a positive orientation toward conflict as a natural phenomenon that creates potential for constructive growth, and a willingness to engage in the conflict in an effort to produce constructive change or growth. Furthermore, he states that rather than looking at isolated conflict episodes, a transformational view seeks to understand how these particular episodes are embedded in the greater pattern of human relationships. In this context, change is understood both at the level of immediate issues and the broader patterns of interaction.

Moreover, a transformative view looks at conflict as an invaluable opportunity to grow and enlarge our understanding ourselves and others rather than viewing conflict as a threat. 
ljtihad, Jurnal Wacana Hukum Islam dan Kemanusiaan, Volume 15, No. 1, Juni 2015: 61-82

In other words, conflict helps us stop, assess and take notice. The central goal of conflict transformation is to build constructive change out of the energy created by conflict, where conflict transformation begins. Lederach argues that by focusing this energy on the underlying relationships and social structures, constructive changes can be brought about. The key point is to move conflict away from destructive processes and toward constructive ones. Therefore, the primary task of conflict transformation is not "to find quick solutions to immediate problems, but rather to generate creative platforms that can simultaneously address surface issues and change underlying social structures and relationship patterns" (Lederach, 2003: 4).

Lederach further explains that transformational framework has three components, in which each represents a point of inquiry in the development of a response to conflict. Those are 1) the presenting situation; 2) the horizon of preferred future, and 3) the development of change processes link to two (Lederach, 2009: 8). Presenting situation connect the present with the past, it does not have the power to change. The potential for change is on "the ability to recognize, understand and redress what has happened and create new structures and ways of interacting in the future". The second inquiry, the horizon of the future is the image of what we wish to create. It points toward possibilities of what could be constructed and built. The process in this transformation is not only a linear process but also a circular process since the orientation of the process not only forward to the future but also back toward to the immediate situation. The third inquiry, the development of change processes must not only promote short term solutions but also build platforms capable of promoting long term social change because the change processes should address both immediate problems and the broader relational and structural patterns (Lederach, 2003: 8).

Lederach further argues that:

"central to transformation is building a base that generate processes that 1) provide adaptive responses to the immediate and future iterations of conflict episodes, and 2) address the deeper and longer-term relational and systemic patterns that produce violent, destructive expressions of conflicts."

In other words, a conflict transformation platform must be short term responsive and long term strategic. One thing that can produce creative solutions to variety problems is an 
adaptive process-structure (Lederach, 2009: 11).

In conflict transformation, peace is viewed as centered and rooted in the quality of relationships. The quality of relationships here includes both face-to-face interactions and the ways in which we structure our social, political, economic, and cultural relationships. In addition, conflict transformation also sees peace as a continuously evolving and developing quality of relationship. "It is defined by intentional efforts to address the natural rise of human conflict through nonviolent approaches that address issues and increase understanding, equality, and respect in relationships" (Lederach, 2003: 4).

Since Lederach's conflict transformation has focused on relationships, patterns, and social structure to deal with the conflict, I think bringing feminism's point of view into the equation is useful. That is in taking gender as one of category of analysis in this theory is much easier without any contradictory between both. We can use a gender perspective to see relationship patterns and the structure of our social, political, economical and cultural relationships. Therefore we can address the issues in conflicts by raising understanding, equality and respect in relationships between women and men.

Furthermore, by including gender in Lederach's approach to peace as a process of developing the quality of relationships will enhance the process of peace since equality, understanding and respect among both man and woman are incorporated.

\section{Lajnah Imaillah Indonesia: a brief historical overview}

To give more contexts about Ahmadi women in Indonesia, this part elaborates the short history of Lajnah Imaillah Indonesia and its development.

Following the existence of Ahmadiyya in Indonesia since 1924, the Lajnah Imaillah Indonesia was established in Padang in 1928, but it was not officially organized. The Lajnah Ima'illah actively ran organizational activities in 1931 in Padang, West Sumatra. The structure of organizational board at that time consisted of several primary bodies held by 5 Ahmadi women, because of the limited number of Ahmadi women. They were Siti Alam Sundari Daud as the leader, Anjar Bahar as the General Secretary, Nani Thali Puar as finance and teacher assisted by Halimah Syair and Nurani Musa (Zulkarnain, 2005: 217). Activities conducted by this pioneer organization were mainly related to the religious activities per- 
ljtihad, Jurnal Wacana Hukum Islam dan Kemanusiaan, Volume 15, No. 1, Juni 2015: 61-82

formed once a week for Ahmadi women and for Ahmadi children. Lajnah Imaillah was just officially established in 1983 after its significant development in West, Central and East Java when they held a congress in Padang and they formed Coordination Body of the Lajnah Imaillah Indonesia (Badan Penghubung Lajnah Imaillah Indonesia, BPLI). It was led by a leader and supported by a vice leader and secretary.

Then in 1987 this coordination body (Badan Penghubung) transformed into Leaders body of Lajnah Imaillah (Badan Pimpinan Lajnah Imaillab), and a leader of BPLI changed into Sadr LI (President). Basically, their activities were related to Jemaat Ahmadiyya activities like pengajian, trainings also held in order to empower women with certain abilities. Up to 1938 the Lajnah Imaillah's members consisted of approximately 40 Ahmadi women and experienced stagnation from 1942-1949. Since 2010, BPLI transformed into Pengurus Pusat Lajnah Imaillah (Central Board of Lajnah Imaillah). Nowadays, PPLI records the number of Lajnah Imaillah members Indonesia is about 13,000 which spread out in 260 branches (PPLI, 2014: 25).

\section{Ahmadi women and conflict violence experiences}

Being a part of Ahmadiyya community that faces conflict and violence, accordingly Ahmadi women also experience the violence. Violence experienced by Ahmadi women in Indonesia are in several forms, from verbal viciousness like bullying, discrimination and physical violence such as expulsion. This part discusses the experiences of Ahmadi women in conflicts that they face in their daily lives.

From my research's participatory narratives, I found that discrimination as Indonesian citizens is like being default for them as Ahmadi, but the degree of discrimination that they face among Ahmadi women from different areas is different in some ways. Some Ahmadi women experienced bullying since they were very young. Other Muslims labeled them with some negative names. In Lombok, people usually called them as "Ahmadiyya ding kong" (they do not know what the meaning of this word till now) (Interview with participants from Lombok, March 2013 and January 2014). In Manislor, they were labeled from light label to the heaviest label that threaten their lives, such as "the followers of religion of kodok (frog)", heretic, deviant, then their blood is halal meaning that they can be murdered in the 
name of religion (Interview with participants from Manislor, April 2013 and February 2014).

Different from their sisters in Manislor and Lombok, Ahmadi women in Yogyakarta is rarely get any labelling or discrimination. They relatively live safely and can observe their religious rituals without any burden. They will get unsafe feeling and uncomfortable situation when there is attack toward Ahmadiyya community in other areas in Indonesia, such as when people attacked Jalsah Salanah event in Parung Bogor in 2005 or the mob and killing of three Ahmadi in Cikeusik Banten in February 2011. Moreover, they can maximize their contribution to society through their social and humanity activities. They also can freely reveal their Ahmadi identity in their neighborhood, workplace and school.

Besides experiencing labeling and stigma, Ahmadi women also face intimidation because of their faith. Some got intimidation from their family and neighborhood to leave their faith. Since they keep their faith, they have to live separately from their big family. These happen to Ahmadi women in Lombok. They were spelled out from their own homes and when they tried to get help from their big family, their family gave requirement to them to leave their faith in order to get back to and live with the family. Because they cannot meet these requirements, they choose to live in Transito building with all its limitations and difficulties (interview with participants from Lombok, May 2013 and January 2014).

Ahmadi women in Manislor got intimidation in a quite long period, from 2002 to 2007 in form of banners which were set up in front of their mosques by non-Ahmadi. The banners written; "Ahmadiyah sesat", "Ahmadiyah Kafir" (Ahmadiyya is deviant, Ahmadiyya is heretics). Every day, in that period, they had to see those banners intimidating them without any action to drop it down although they are in their own village Interview with Ahmadi women in Manislor, March 2013, January 2014). Furthermore, during that period, sometimes there were some unidentified people who blow Molotov bomb to their mosque, tried to burn it at any time, during daylight or night. In addition, not only mosques which were under target, but also their houses which nearly located with the mosques.

In terms of physical violence, Ahmadi women in Manislor experienced it several times. During the period 2001-2005, some Ahmadi women experienced their houses attacked. 
ljtihad, Jurnal Wacana Hukum Islam dan Kemanusiaan, Volume 15, No. 1, Juni 2015: 61-82

People coming to and pelt their settlements with stones. When it was happening, they had to run or hide into a safer place and some of them got injured because of the stones. Some of houses' roof were also broken. Besides that, some mosques were burnt down for several times. One mosque located in Maniskidul that was newly built and then destructed by people who do not like it just a day before Ramadhan in 2001, the debris is still present till now. They cannot rebuild it because people do not allow them to do so, thus they let it as it is as their monument of remembrance how was the violence happened.

When they started to take active actions by confronting people or apparatus who would seal or attack their mosque, sometimes, Manislor Ahmadi women had to face head to head with them. They stood on the first line arm in arm among them and they made a posse together to protect their mosque from sealing and attack while they were crying and praying. These actions actually place themselves in the most vulnerable positions because if the attackers went forward, they would be the first target. Therefore, police asked them to go inside the mosque rather than stay arm in arm in front of the mosque. At one occasion when the situation was getting chaotic, they surrendered and agreed to go inside the mosque. However, in other occasion, they defended the mosque while holding hands stronger among them, although they had to face intimidation and violence (Interview with participants, Manislor, March 2013).

For Ahmadi women in Manislor, they will never forget about those experiences. Nowadays, their circumstances are better than before. According to them, Joint Ministerial Decree (Surat Keputusan Bersama, known as SKB) issued in 2008, on one hand localize and prohibit them doing missionary. On the other hand, it gives them more freedom in doing religious activities in their village although under the eyes of people.

Besides getting stigma and experiencing violence, Ahmadi women in Manislor also face difficulties in their citizenship rights. The most crucial is they cannot register their marriage in district Kuningan. Local government has made a rule which not allowing Ahmadi registering their marriage in Kuningan district. Therefore, Ahmadi should move to another district in registering their marriage. And it disadvantage them in getting health facilities for their new family and kids. They also have not gotten their e-KTP (electronic ID card) yet although they have been photographed for those e-KTP. 


\section{Ahmadi women in conflict transformation process}

This part discusses the stages experienced by Indonesian Ahmadi women in dealing with conflict with violence they experience from 2000-2014. As a part of Ahmadiyya Muslim community, Ahmadi women through its auxiliary organization, Lajnah Imaillah Indonesia, take part actively in all activities which involved all aspect of life. Since its establishment, LI Indonesia, based on its constitution, mainly work to empower their members through religious and social activities. Because of the small number of their members and their lack of religious knowledge in the first development of the organization, their first concern is the improvement of their members' religiosity. Therefore, their activities mainly focuses on educating their member through pengajian, learning Quran, many activities to encourage their member to improve their obedience (taqwa). Their social activities also have been started but mainly for their community member, like giving aid to members who are in difficult economic situation and founding cooperation for their members. They also started to do social activities to larger community outside their community but still in limited amount.

Ahmadi women's attitude is based on what have been suggested by the founder of Ahmadiyya, Mirza Ghulam Ahmad who said that Ahmadi should obey the law of the state where they live although the government is an oppressive government. All members are suggested to be active in women activities in their place such as PKK (an organization to empower women to take part in Indonesia development), posyandu (a place to maintain heatlh that is from, by and for community under the supervision related paramedic, Departemen Kesehatan RI, 2006). and build a good relationship with other women's organization and also with local leaders in their area like village chief, sub-district head, regent and governor and their wives.

One of the most prestigious efforts done by Lajnah Imaillah is they contribute the biggest number of eye donor in Indonesia started from 1985. They always advise their members to participate to be eye donor so as blood donor. Nowadays, the number of eye donor candidates is 7,549 women and 161 women have had donated their eyes. For blood donors, it is numbered at 6,788 women (PPLI, 2012: 42).

Although Lajnah Imaillah has involved in several kinds of activities in communities and in some levels they can lessen misunderstanding about Ahmadiyya in Indonesia through their 
ljtihad, Jurnal Wacana Hukum Islam dan Kemanusiaan, Volume 15, No. 1, Juni 2015: 61-82

social activities such as blood donor, eye donor, social services, however, violence toward them is not going down since Joint Ministerial Degree /SKB 2008, even in some places they were going up. They have to face the reality that they are prone to any violence from other communities because of their faith. Their efforts to participate more in community seemingly not really bring about any difference to the level of violence that their community faces. Several times their mosques in becoming the target to be closed and broken down in preventing them doing their religious activities, such as the sealed and zinc fenced of Al Mishbah Mosque in Bekasi West Java, the attack on their religious activities in Wanasigra, May 2013 and recently the sealing of their mosque in Ciamis by local government just a day before Ramadhan on June 26, 2014 (http:/ /indonesiatoleran.or.id/2014/06/kronologi-penyegelan-masjid-nurkhilafat-jemaat-Ahmadiyah-ciamis/ accessed 20 ${ }^{\text {th }}$ July 2014).

From LI's experience in dealing with conflict with violence and discrimination during 1998 to 2014 by exercising their agencies, there are three stages of conflict transformation process that those Ahmadi women develop. The next part will elaborate those three stages.

\section{First stage: admitting the circumstances by relying on government}

At first stage, they admitted their position as victim, minorities whose destiny and position is determined by others, other Muslims and several local governments blame them because of their faith that different from mainstream Muslims. They are deviant, misleading, and apostle, therefore they have to be condemned, diminish or even murdered. They are the cause of violence that happens, they disturb the harmonious life in Indonesia, they defame the purity of Islam, and hence, they have to get the consequences.

Although they repudiate all accusations toward them about their faith, during this stage, they kept silent, they only let people harassed them verbally and attacked their properties, mosques without any resistance. Moreover, frequently they could not defend their properties and rights, even they were forced to surrender not by their own willing. If people finished cracking down their mosque, the government also blamed them and would seal their mosque to prevent them doing their religious activities. When people came and attacked again, they would also let it happen again and again. 
They have to be ready for any label, stigma, discrimination, violence and they did not have chance to defend their rights, or when they had chance to secure it, the apparatus and people did not allow them to do so. This stage shows that it is their destiny to be mistreated and discriminated by other Muslims who do not agree with them, or even worse by the State. It is their consequences to be different from other Muslims in theological matter.

Ahmadi women from three areas of this research have different experience relating to this stage. Many of them experienced stigma, labeling. The others experienced intimidation and verbal harassments. However, they have the same reaction towards it. This stage ranges from 2000 to 2005.

Keeping silent and admitting the violence they experienced were the reactions from Ahmadi women in Manislor. They only kept silent when people harassed them verbally by calling them as deviant, kafir, sesat. They also let people intimidate them verbally and did not reply anything to them. They made themselves accustomed to any kind of intimidation they got. Somehow, they have internalized the stigma and label from other Muslims as the consequences therefore there was no need to respond.

Moreover, related to violence done by people toward their properties, they did not do anything to protect their properties. When people attacked them, they would only hide to a safer place if they could and let people destroy their houses and mosques. If people finished their actions, Ahmadi would quickly renovate their properties to prevent the police investigating the violence case. Because if the police came and investigated the case, usually the police would give a police line to their properties, particularly their mosques which means that they are not allowed to use it to do their religious activities.

Moving to Ahmadi women in Lombok, they experience the hardest discrimination and violence compared to other Ahmadi women in Indonesia, unfortunately they are still experiencing till now. They are evicted from their own houses because of their faith and cannot go back to their own houses. They have to live far from their origin; families and where they used to be belong. They lose their properties, and also their jobs.

They experience all kind of violence, from stigmatization, labeling and physical violence. They experienced labeling since they were very young when they were still unable to understand the differences of their faith with others. People label them with terms that are 
ljtihad, Jurnal Wacana Hukum Islam dan Kemanusiaan, Volume 15, No. 1, Juni 2015: 61-82

unfamiliar, no meaning and even they do not understand the meaning till now. They did not respond to those kinds of discrimination and violence. They kept soundless although they felt painful in their heart.

When there was an attack toward Ahmadiyya community, mostly, the apparatus force Ahmadis not to guard themselves. Even the apparatus forced them to be evacuated in the name of security. Living as IDP was also not their own choice, but they were forced to. Now they have living in Transito for more than eight years.

There are some reasons I found from my interviews why Ahmadi women used to keep silent and did not share their experience to others and also do not react toward violence that they experience. Firstly, they believe that what they experience is a consequence for them of being Ahmadi, therefore they have to admit all those discriminations and violence and have to accustom to those circumstances in their lives. Secondly, they were afraid of giving respond by resisting people who attack them or government who ban them to do their religious activities because they have not known yet about their rights as Indonesian citizens who have religious freedom to do religious activities based on their faith and they did not know the legal status of their cases. Thirdly, there was a role from the apparatus who made the situation worse and even they make up the situation which made Ahmadi women anxious.

In this stage, we can say that Ahmadi women relied on government's help and policy related to any discrimination and violence that they experienced.

\section{Second stage: standing for and defending rights}

After experiencing conflict which was followed by persecution and violence for more than six years, Ahmadi women started to get attention and help from other organizations which care about their life. As a result, it encouraged them to be more active in dealing with conflict that they faced.

In this second stage, Ahmadi women started to play more active by taking their positions not as passive victims, but as active victims. They started to act to defend their rights. If there is an effort to seal their mosque or prevent them doing their religious activities, they stood up and defended their rights. They also spoke out to people about their experience on violence and discrimination. This phase happened from 2005 to 2011. 
They started to answer many invitations coming from other organizations which care about them. They eagerly used these opportunities to speak up their voice and show their visibilities. For examples, giving testimonies in event held by Komnas Perempuan (Woman National Commission) about the violence toward them. They also actively take part in several discussions on religious freedom held by organizations which concern about it.

In this stage, besides advocated by their umbrella organization, Jemaat Ahmadiyah Indonesia which has formed Lembaga Bantuan Hukum (Legal Aid Institute) concerning about issues on the persecution of their community from other communities and also from government, they also were still helped by other organizations such as NGO, Komnas Perempuan (National Commission of women). LBH JAI (Lembaga Bantuan Hukum Jemaat Ahmadiyah Indonesia) educated them about their rights and suggested them to protect their properties. They come when they are invited. They talked when they were asked to do so, they would explain if they were asked to.

As Indonesian citizens, they actively participate in all activities held in community. In this stage, as a national organization for Ahmadi women, Pengurus Pusat Lajnah Imaillah always participate when they get invitation from other organization in seminar, conferences, both social and religious organizations such as ICMI (Ikatan Cendekiawan Muslim Indonesia), Puan Amal Hayati with its activities of iftar and saur gathering every year, ICIP (International Center for Islam and Pluralism), YJP (Yayasan jurnal Perempuan). They also have several cooperation with other women organizations such as Muslimat NU, Fatayat NU (BPLI, 2008: 45-47).

Based on their annual report in 2008, LI also took a place in responding several violence happened to them, for example they gave testimony in a press conference held by Yayasan Jurnal Perempuan in Jakarta about "Selamatkan Ibu dan Anak Abmadiyah dari Kekerasan" (Save Ahmadi women and children from violence). They also attended and gave testimony in launching of monitoring result on violence actions toward Ahmadi women and children ("Peluncuran hasil pemantauan tindak kekerasan terhadap Ibu dan anak. Ahmadiyah") in National Commission of Woman (Komnas Perempuan). They also did use mass media to respond to violence that happen to them. They talked in radio program in Green Radio Jakarta by giving press release on the issue on saving Ahmadi Women and children from violence and 
ljtihad, Jurnal Wacana Hukum Islam dan Kemanusiaan, Volume 15, No. 1, Juni 2015: 61-82

the existence of Lajnah Imaillah and did interview with televisions and newspapers (BPLI, 2008: 46-47). This is may be the first time Ahmadi women talk publicly about their experience on violence that they experience. In this occasion they started to speak out when there is other organization which support and call them to do so. Before that, Ahmadi women's voices were unheard about the violence that they experience. Mostly, only Ahmadi men's voices which was heard.

In addition, active actions were also initiated in this stage. It is noted in Lajnah Imaillah Indonesia annual report in 2008, they sent a formal mail to Ministry of Women Empowerment to have a visit and build a relationship. Accordingly, they started to build good relationship with several various organizations.

Although they have been doing active actions in dealing with the escalation of conflict and violence towards them in 2005 - 2008 periods, however it seems that their efforts were not enough to minimize the number of violence and discrimination toward their community. Even more, on June 2008 the government through Ministry of Religious Affair Maftuh Basyuni, Ministry of Home Affair Mardiyanto and The Attorney General Hendarman Supandji, those three ministers signed and issued SKB, a joint ministerial decree which accusing Ahmadiyah as spoiling Islam and furthermore banning their activities. This SKB states that Ahmadi are not allowed to open and proselytize their faith that is distinct from other mainstream Muslims.

This SKB actually also warns Muslims in Indonesia not to do violence toward Ahmadiya community. Unfortunately, the lack of socialization of the content of this SKB resulted in misunderstanding and different interpretation on this SKB. Some local government translated this SKB into local law which ban Ahmadiyya activities in their region such as in West Java, West Sumatra, and East Java. Therefore some radical groups think that it means Ahmadiyya should be banned and can not live in Indonesia and or practice their religious activities based on their belief. Consequently, the number of attack and violence toward Ahmadiyya community were increasing instead of decreasing.

This SKB, directly influenced the attitude of Ahmadi women. Hence, they were more wary in their activities. They were afraid to clarify misunderstanding about their faith because they are afraid of breaking the law and Joint Ministerial Decree SKB which state that 
Ahmadi are not allowed to open and proselytize their faith that are different from other Muslims. However, in fact, their choice not to clarify misunderstanding about their faith resulted on worse treatment toward them and more violence toward them.

\section{Stage three: participation and contribution}

Having those harsh experience for several years, Ahmadi women started to evaluate themselves. They see inside themselves, individually and organizationally. They assess their own attitude and also their organization activities and their implication toward their existence and security. The presenting situation in which Ahmadi women experience violence, made them to connect the present events with the past, although there was no power yet to change, but there is the potential for change, as Lederach said is on "the ability to recognize, understand and redress what has happened and create new structures and ways of interacting in the future" (Lederach and Maiese, 2009: 8).

Based on their experience in some areas, if their members of Lajnah Imaillah participate actively in their neighborhood and society even more they have responsibility in local government such as Ketua RT (a neighborhood consisting around 20-30 houses), Ketua RW (a neighborhood consisting 2-5 Rukun Tetangga , leader in neighborhood), they found out that their existence and security are protected by society in their neighborhood. For example in Lenteng Agung, where one of Lajnah Imailah is becoming Ketua RW, and she shows very good performance so that her society are happy with her and they can live in harmony. Once, when there is a rumor or efforts to attack Ahmadis in that area, people try their best with several ways to prevent it. Therefore, they realize that their existence and security cannot be separated from their neighborhood and larger society. On the other hand, in most areas where their community face violence and persecution, it is found that most of their members living centralized in one area such as in one village or one kampong, for example Manislor. Consequently, most of them spend most of their time with their own community in their daily lives. All daily activities and religious activities are mostly done with their own community, with almost the same people. Their only chance interacting with non-Ahmadis is in their workplace.

These circumstances, on one hand are good for them in term of doing religious activities. They can easily organize and mobilize their members to do all religious activities, even 
ljtihad, Jurnal Wacana Hukum Islam dan Kemanusiaan, Volume 15, No. 1, Juni 2015: 61-82

they can have prayers five times a day together, pengajian every week, and it is good for their internal education and monitoring as a religious organization. On the other hand, since most of their time have been spent among their own community both in religious life and social life, their interaction with non Ahmadi is not quite often. As a result, non Ahmadi around them see them as exclusive and closed community. Moreover, non Ahmadi see them as others who are different from them and having very different faith with them.

Based on experience in the previous stage, Ahmadi women finally comprehend that although they have tried to participate in larger society, however many of their members are rarely active in their neighborhood, or if they are active in social activities, most of the time they rarely declare about their Ahmadi identity. It is because they thought that people have already known about them and their Ahmadi identity like Ahmadi women in Manislor so that there was not a need to talk about their identity, or because they were afraid of revealing their identity because they thought that saying about their identity as Ahmadi would break SKB from three ministries. In the previous stage, they started to take part actively in society both in social activities and also in clarifying about their condition, situation and thoughts related to some violence happened to them because of their faith. After they interact with larger community, they finally realize that not all people know that they are Ahmadi. Therefore, in the following time when they got chance to have friendly match with other clubs they then introduce themselves as Ahmadi women Conflict will always be presence in our community because Indonesia was built from many different ethics, religions, faiths and cultures. Conflict that Ahmadiyya community faces and experience is inevitable since there is always different interpretation and understanding among Muslims. Therefore, efforts on changing or transforming conflict from conflict which bring about violence and discrimination into conflict which strengthen the community and Indonesia are needed.

The second inquiry of conflict transformation is the horizon of the future, is the image of what we wish to create. It points toward possibilities of what could be constructed and built (Lederach and Maiese, 2009: 8). From Ahmadi women's experience, they wish to live in peace with other Muslims in Indonesia, therefore they need to build good relationships with other communities. 
The third inquiry, the development of change processes must not only promote short term solutions but also build platforms capable of promoting long term social change because the change processes should address both immediate problems and the broader relational and structural patterns (Lederach and Maiese, 2009: 8).

Besides attending many invitations from other organizations, Lajnah Imaillah also started to actively contact other organizations by holding activities that involved other organizations. In this stage they started to reach out, extend their activities not only for their members exclusively but also for women outside Lajnah Imaillah. In this stage they continue their efforts that they have been carrying out to give service to society.

In the third stage, Ahmadi women start to show their action as Indonesian citizens who have the same rights as others. They responded to any discrimination and violence regarded on conflict because of their faith by being an active agent in the process of conflict transformation. Metaphorically to Ortner's theory on agency (Ortner, 1996), Ahmadi women started to change their role in the play. They initiate resistance in the former stage and now they expand their space by going out from their closed community (Ahmadiyya community) into outer and wider community. Interestingly, they do not bring their bitter experience to get attention from others, but they bring and show their potentials, skills and abilities to give contribution and help others to get attention from people. Indeed, they already run their programs in giving service to others regularly before, but in this stage they make it as programmed activities in which they give special attention, time and fund to implement it.

On this stage, there are two forms, internal and external efforts done by Ahmadi women. The first form is strengthening Ahmadi women themselves in order to strengthen the community. As we can see the circumstances, conflict, challenges and threats are conversant for Ahmadiyya community in Indonesia. Realizing that position, Lajnah Imaillah Indonesia is aware of the need for giving strength and capability to their members in order to face and deal with it. What make them in difficult situations now is their faith that seen to be different from the majority in Indonesia. And faith for them is the ultimate basis for them in their live, therefore, to preserve their faith but also to face the reality.

Inside, PPLI educate their members to behave as what the Prophet Muhammad suggest with akhlakul karimah (righteousness behavior) in their daily lives since actions are more 
ljtihad, Jurnal Wacana Hukum Islam dan Kemanusiaan, Volume 15, No. 1, Juni 2015: 61-82

important than debate or argument. As for Ahmadi women, debating and arguing about Ahmadiyya faith and beliefs is not their skills, and based on their slogan "Love for all hatred for none", they have to serve for humanity, therefore they choose using their skills and abilities in parenting, health and medical skills.

Relating to their relationship with other communities, they suggest their members to have a good relationship with their neighbors. They give guidance, that an Ahmadi family should build good relationship with their neighbors, at least 40 families consist of ten houses in front of their house, ten houses behind, ten houses on the right side and ten houses on the left side. Good relationships with neighbors is very crucial for them as part of society.

In national organization level, PPLI initiate and sponsor events which involved people from other communities. The events are discussed and planned carefully by the PPLI in Bogor and socialized within their members around Indonesia to get support. The events were held around Indonesia. They call their programmed events as a programmed rabtah (building relationship). Accordingly, PPLI planned what they call "programmed rabtah". Rabtah means developing good relationship with others. They believe that if they have good relationships with non-Ahmadis, violence and discrimination toward them will eventually declining.

Through rabtah, they hold activities which involved many people from non Ahmadi participants. They choose general theme that are needed by people such as parenting, health and crafts in which they have several experts on those themes. In this program they target government programs such as PNPM (national programs to reduce poverty, especially that based on community empowerment), HIMPAUDI (organization for early childhood educators and teachers), PAUD (early childhood education), PKK, and Posyandu in which community and governmental leaders are able to attend together with people. Besides, the programs do not only stop for events but they have to carry on it by keeping their good relationship with people who have already join the program. By keeping this good relationship, they hope that people will get information about Ahmadiyya from its original sources, Ahmadi themselves

They choose parenting and health as the topic as for those topics are neutral topics. PPLI specially forms a team for giving parenting workshop around Indonesia. Through their lower organization, regional Lajnah Imaillah Organization they build relationship with local 
leaders to make their program happen. They have started this program from July 2013 into June 2014. The purpose of this program is to reduce people's misunderstanding on Ahmadiyya and to reach areas which are unreachable before (Material of Lajnah Imaillah committee members meeting 2013).

In these activities, they open their identity as Lajnah Imaillah Indonesia. These parenting workshop have been held in several areas in Indonesia and got good response from organizations they cooperate with. Based on my observation the materials that they give in parenting workshop mostly are Islamic values from Qur'an and hadits.

\section{Concluding remarks}

Conflict is normal and conflict is motor change in conflict transformation context. Conflict that Ahmadi women face and experience eventually become a motor change for them. It does not change either their organizational structure or their faith, even it strengthen their faith and make them more resilient but in the end it transforms their attitude and expand their activities in dealing with those persecution and violence. Conflict that bring violence used to only place them in oppressed position now make them realize that they can be an active agent of peace in plurality of Indonesia.

In other words, conflict and violence do not only bring about negative effects but also positive effects for Ahmadi community internally and also for Indonesia society at large. Ahmadi women can manage conflict and violence that they experience into something positive in which they do not blame the perpetrators but they look back into themselves to see and adjust with the circumstances without changing their faith. Ahmadi women are trying to transform conflict which brought to violence to their community into conflict which make them having closer relationship and more open to other communities to make a peace.

\section{Bibliography}

Amin, Ali. "Intra-Religious Persecution in West Java. As Case Study of Ahmadiyah Community in Manislor Kuningan." Universitas Gadjah Mada, 2005.

Anam, Syaiful. "Reproduksi Kekerasan Kolektif: Studi Kasus Konflik Ahmadiyah Di Lombok NTB Tahun 1998 - 2006.” Magister Perdamaian dan Resolusi Konflik, Sekolah pasca sarjana Universitas Gadjah Mada, 2011. 
ljtihad, Jurnal Wacana Hukum Islam dan Kemanusiaan, Volume 15, No. 1, Juni 2015: 61-82

Berg, Ellen Ziskind. "Gendering Conflict Resolution.” Peace and Change 19, no. 4 (October 1994): 325-48.

BPLI, Badan Pimpinan Lajnah Imaillah Indonesia. Laporan Kegiatan Tabunan Badan Pimpinan Lajnah Imaillah Indonesia. Annual Report. Jakarta: Badan Pimpinan Lajnah Imaillah, September 2008.

Budiwanti, Erni. "Pluralism Collapses: A Study of Jama'ah Ahmadiyah Indonesia and Its Persecution." Research Center for Regional Resources, Indonesian Institute of Sciences (PSDRLIPI) and Asia Research Institute - National University of Singapore, ARI working paper series, 2009.

Galia, Golan. "The Role of Women in Conflict Resolution.” Palestine-Israel Journal of Politics, Economics and Culture 11, no. 2 (2004): 92-96.

Gosh, Huma Ahmed. "Ahmadi Women Reconciling Faith with Vulnerable Reality through Education." Journal of International Women's Studies 8 (November 1, 2006).

Gualtieri, Antonio. Ahmadis: Community, Gender, and Politics in Muslim Society. Montreal: McGillQueen's University Press, 2004.

Hutadjulu, Dyana Savina. “The 'Other' Female Tale: An Intersectional Analysis of the Ahmadiyah Women and Girls' Experience in Indonesia.” Research Paper. Graduate School of Development Studies, The Hague The Netherlands, 2009.

Ingkretia, Enny. "Symbolic Convergence in Group Rhetoric (Study of Rhetorical Vision as the Cohesiveness Indicator in Ahmadiyya Muslim Community in Indonesia)." In Proceeding of the International Conference on Social Science, Economics and Art 2011, 2011.

Lederach, John Paul. The Little Book of Conflict Transformation. Intercourse: Good Books, 2003. Lederach, John Paul, and Michelle Maiese. "Conflict Transformation: A Circular Journey with a Purpose." New Routes, a Journal of Peace and Research and Action, Conflict Transformation: Three lenses in one frame, 14, no. 2 (2009): 7-10.

Ortner, Sherry B. Making Gender: The Politics and Erotics of Culture. Boston: Beacon Press, 1996.

PPLI. Laporan Tabunan Pengurus Pusat Lajnah Imailah Indonesia. Annual Report. Pengurus Pusat Lajnah Imaillah, October 2012.

PPLI. Laporan Tabunan Pengurus Pusat Lajnah Imaillah Indonesia. Annual Report. Bogor: Lajnah Imaillah Indonesia, October 2014.

Pujianto, Agus. "Evaluasi Peran Brimob Dalam Intrevensi Konflik (Studi Kasus Satuan Brimob Polda NTB Dalam Intervensi Konflik Ahmadiyah Dengan Masyarakat Di Kecamatan Lingsar Lombok Barat Tahun 2006).” Magister Resolusi Konflik, Sekolah Pasca SarjanaUniversitas Gadjah Mada, 2007.

Trianita, Winy. "Women's Agency in Religion: The Experience of Ahmadi Women in Indonesia." Universitas Islam Negeri Syarif Hidayatullah, 2009.

Zulkarnain, Iskandar. Gerakan Ahmadiyah di Indonesia. Yogyakarta: LKiS, 2005. 